\title{
Estimating Piacenzian Sea Surface Temperature Using an Alkenone-Calibrated Transfer Function
}

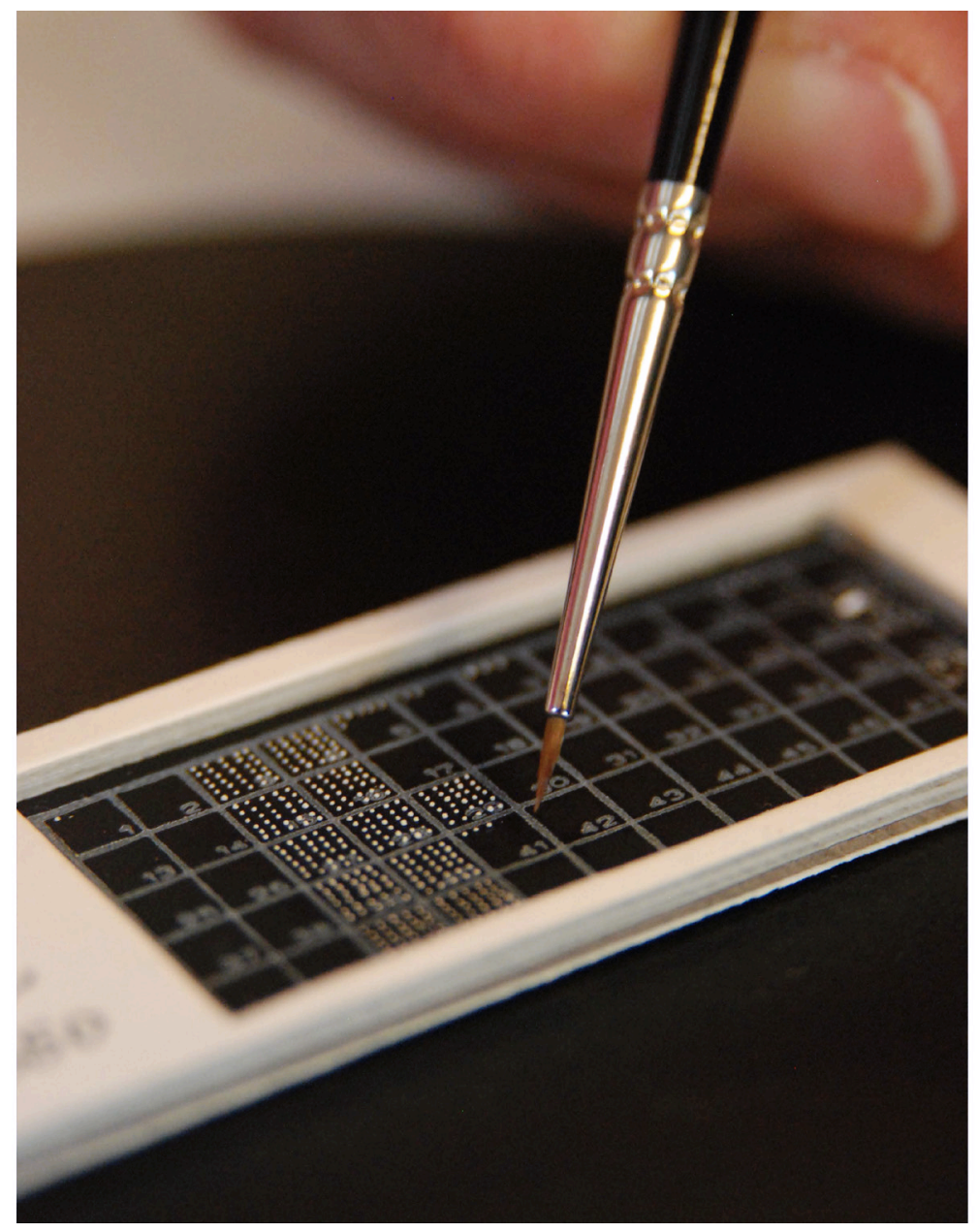

Scientific Investigations Report 2021-5051 
Cover. Planktic foraminifer specimens, arranged by species in numbered squares on a micropaleontological slide, provide assemblage data for quantitative analyses of sea surface conditions. Photograph by Christina Riesselman, U.S. Geological Survey. 


\section{Estimating Piacenzian Sea Surface Temperature Using an Alkenone-Calibrated Transfer Function}

By Harry J. Dowsett, Marci M. Robinson, and Kevin M. Foley

Scientific Investigations Report 2021-5051 


\section{U.S. Geological Survey, Reston, Virginia: 2021}

For more information on the USGS - the Federal source for science about the Earth, its natural and living resources, natural hazards, and the environment—visit https://www.usgs.gov or call 1-888-ASK-USGS.

For an overview of USGS information products, including maps, imagery, and publications, visit https://store.usgs.gov/.

Any use of trade, firm, or product names is for descriptive purposes only and does not imply endorsement by the U.S. Government.

Although this information product, for the most part, is in the public domain, it also may contain copyrighted materials as noted in the text. Permission to reproduce copyrighted items must be secured from the copyright owner.

Suggested citation:

Dowsett, H.J., Robinson, M.M., and Foley, K.M., 2021, Estimating Piacenzian sea surface temperature using an alkenone-calibrated transfer function: U.S. Geological Survey Scientific Investigations Report 2021-5051, 17 p., https://doi.org/10.3133/sir20215051.

Associated data for this publication:

Dowsett, H.[J.], Robinson, M., and Foley, K., 2015, A global planktic foraminifer census data set for the Pliocene ocean: Scientific Data, v. 2, article 150076, 6 p., https://doi.org/10.1038/sdata.2015.76.

Dowsett, H.J., Foley, K.M., Robinson, M.M., and Herbert, T.D., 2017, PRISM late Pliocene (Piacenzian) alkenone-derived SST data: U.S. Geological Survey data release, https://doi.org/10.5066/F7959G1S.

Robinson, M.M., Foley, K., Dowsett, H.J., and Spivey, W., 2019, A global planktic foraminifer census data set for the Pliocene ocean, addendum: National Oceanic and Atmospheric Administration, National Centers for Environmental Information [formerly National Climatic Data Center] website, https://www.ncdc.noaa.gov/paleo/study/27310.

ISSN 2328-0328 (online) 


\section{Acknowledgments}

The research described in this report used samples provided by the International Ocean Discovery Program (IODP), the Ocean Drilling Program (ODP), and the Deep Sea Drilling Project (DSDP).

Funding for this research was provided by the U.S. Geological Survey (USGS) Land Change Science Program through the Geological Investigations of the Neogene Project. Tim Herbert of Brown University collaborated on analysis and discussion of alkenone data. Peer reviews by Thomas Cronin and Summer Praetorius of the USGS were helpful. 



\section{Contents}

Acknowledgments ……...................................................................................................................

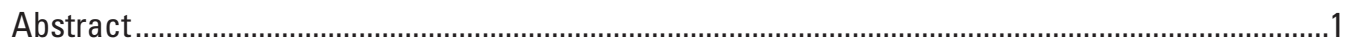

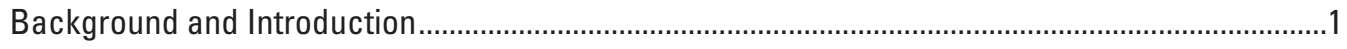

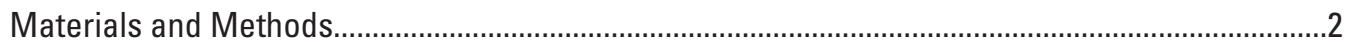

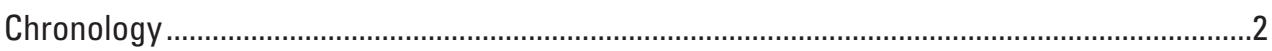

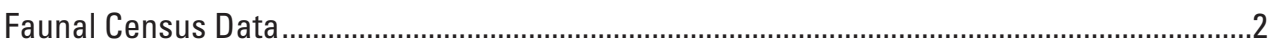

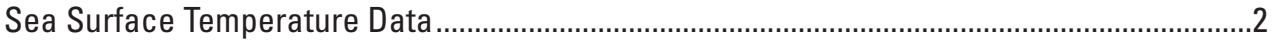

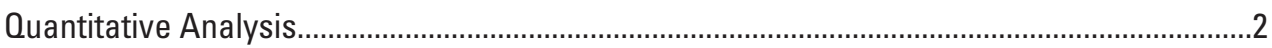

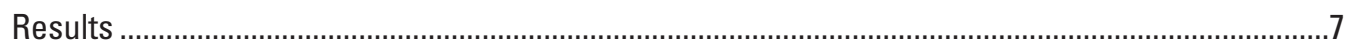

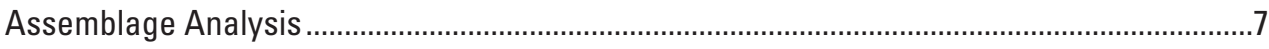

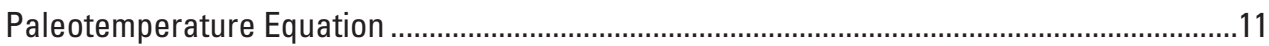

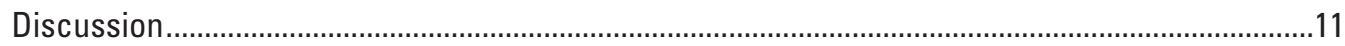

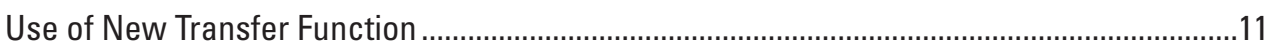

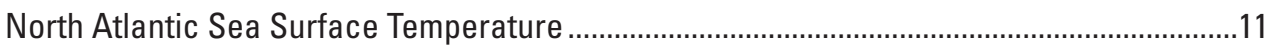

Summary and Conclusions....................................................................................................

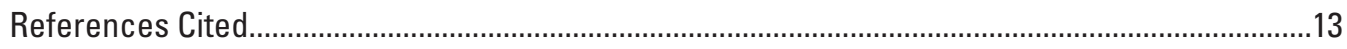

Appendix 1. Species List ................................................................................................

\section{Figures}

1. Graph showing the PRISM3 interval (also known as the mid-Piacenzian Warm Period [mPWP]) in relation to paleomagnetic reversal stratigraphy, planktonic foraminiferal zones, and the long-term climate evolution of the Pliocene Epoch..............3

2. Graph of results of factor analysis of Piacenzian planktonic foraminiferal assemblages showing sample loadings on Factor 1 and Factor 2 ...................................8

3. Graphic representation of the assemblage description matrix showing how foraminiferal species score on five factors and percentage of information explained

4. Dendrogram and map showing results of cluster analysis of planktonic foraminiferal assemblages from 31 sites and geographic distribution of

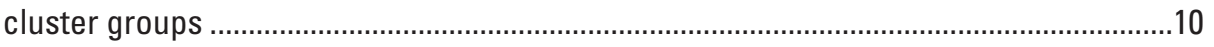

5. Map showing PRISM3 mean sea surface temperatures (SST) for 31 sites in the North Atlantic Ocean .....

\section{Tables}

1. Site locations, alkenone-based sea surface temperature estimates, number of samples, and faunal abundance data used in this study

2. Factor loadings explaining the relative contribution of the five factors to the faunal assemblage at each site

3. Factor scores for the five-factor model indicating influence of taxa from 31 sites on factors. 


\section{Conversion Factors}

Temperature in degrees Celsius $\left({ }^{\circ} \mathrm{C}\right)$ may be converted to degrees Fahrenheit $\left({ }^{\circ} \mathrm{F}\right)$ as follows: ${ }^{\circ} \mathrm{F}=\left(1.8 \times{ }^{\circ} \mathrm{C}\right)+32$.

Temperature in degrees Fahrenheit $\left({ }^{\circ} \mathrm{F}\right)$ may be converted to degrees Celsius $\left({ }^{\circ} \mathrm{C}\right)$ as follows: ${ }^{\circ} \mathrm{C}=\left({ }^{\circ} \mathrm{F}-32\right) / 1.8$.

\section{Abbreviations}

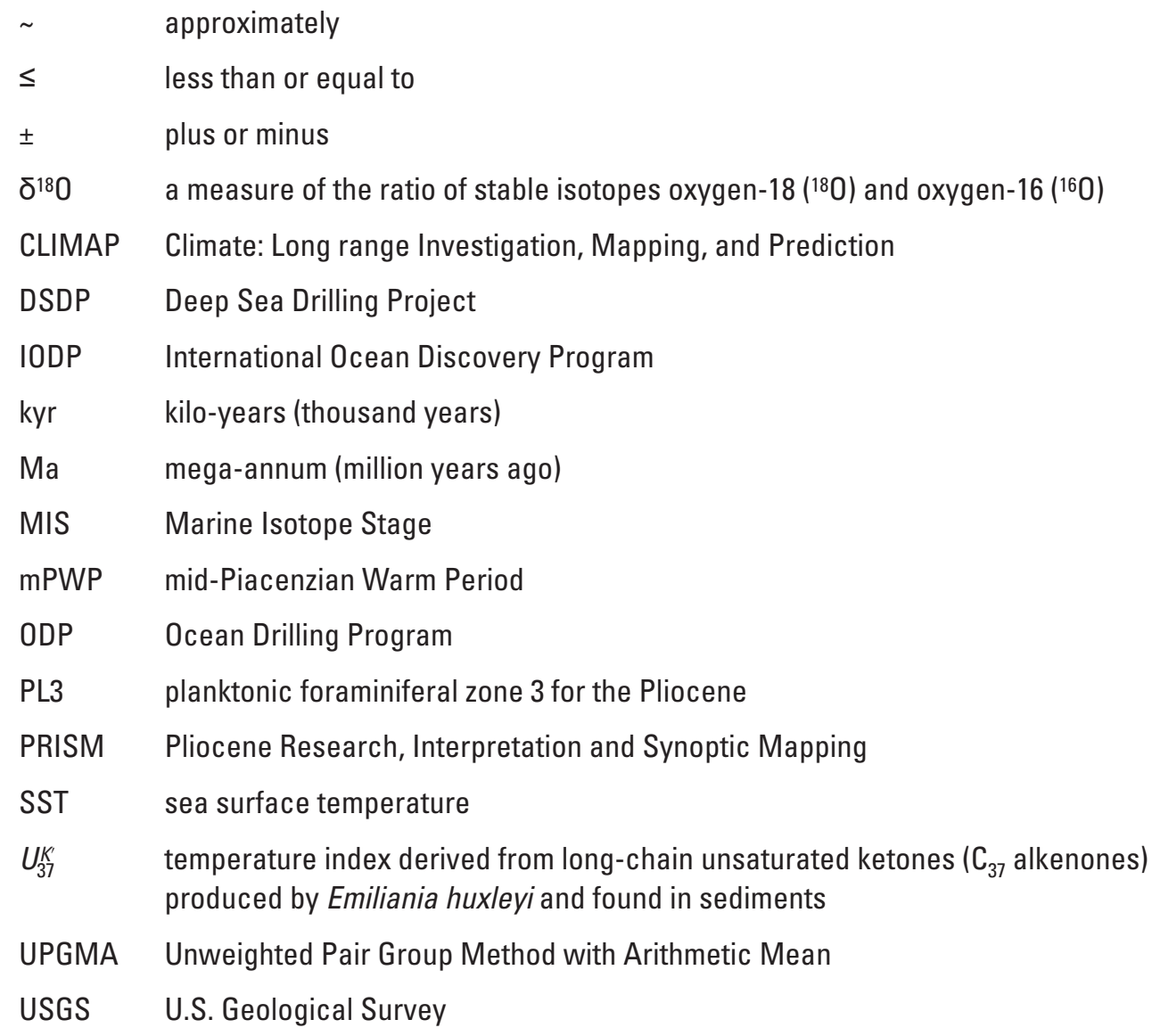




\title{
Estimating Piacenzian Sea Surface Temperature Using an Alkenone-Calibrated Transfer Function
}

\author{
By Harry J. Dowsett, Marci M. Robinson, and Kevin M. Foley
}

\section{Abstract}

Stationarity of environmental preferences is a primary assumption required for any paleoenvironmental reconstruction using fossil materials based upon calibration to modern organisms. Confidence in this assumption decreases the further back in time one goes, and the validity of the assumption that species temperature tolerances have not changed over time has been challenged in Pliocene studies. We use paired $U_{37}^{K^{\prime}}$ (unsaturated ketones with 37 carbon atoms) sea surface temperature (SST) and faunal assemblage data to directly calibrate North Atlantic Piacenzian planktonic foraminifer assemblages to Piacenzian alkenone paleotemperature estimates to provide an alternative paleoceanographic reconstruction approach that does not rely on stationarity. In doing so, we extend Pliocene SST estimates to sites where only quantitative faunal assemblage data were previously available and improve the spatial resolution of the North Atlantic SST reconstruction.

\section{Background and Introduction}

Foraminiferal census data have been routinely used to quantitatively estimate paleoceanographic temperature since the 1970s with the introduction of a method for deriving factor analytic transfer functions (Imbrie and Kipp, 1971). The Imbrie-Kipp method relates modern species abundance data to physical oceanographic parameters to derive equations that are then used on fossil assemblages to make quantitative estimates of paleoenvironments. This technique was used extensively in (1) the reconstruction of the Last Glacial Maximum by members of CLIMAP (Climate: Long range Investigation, Mapping, and Prediction) (Cline and Hays, 1976) and (2) the later reconstruction of the Last Interglacial (CLIMAP Project Members, 1984). The Imbrie-Kipp method and other methods like the Modern Analog Technique, in which fossil assemblages are assigned the sea surface temperature (SST) of the most analogous assemblage within a modern dataset (Hutson, 1980), and methods using artificial neural networks to discover patterns within data (for example, Malmgren and Nordlund, 1997; Malmgren and others, 2001) all rely on the basic assumption that modern foraminiferal faunas can be used as analogs to interpret Quaternary assemblages. Extensions of these methods to deeper time settings like the Piacenzian Age (3.60 to 2.58 million years ago [Ma]) of the Pliocene Epoch require additional assumptions to address extinction and evolution of species since that time (Keigwin, 1976; Thunell, 1979; Dowsett and Poore, 1990; Sabaa and others, 2004) and require the ability to correlate time series data among many sites across all ocean basins (Dowsett and Robinson, 2006). These two challenges-assumptions regarding species tolerances and uncertain chronologic correlationinsert uncertainty into pre-Quaternary paleoenvironmental reconstructions.

Paramount to all paleoenvironmental reconstructions, whether paleontological or geochemical in nature, is the concept of stationarity, the assumption that the relations among variables have not changed over time. Faunal assemblagebased reconstructions depend on the assumption of stationarity of environmental tolerances or preferences of the extant species that are in the fossil assemblage. In addition, now extinct species must be assigned the tolerances of extant taxa on the basis of ancestor-descendent relationships and (or) similar spatial distributions. For example, the U.S. Geological Survey (USGS) reconstructions of the North Atlantic paleoclimate through the Pliocene Research, Interpretation and Synoptic Mapping (PRISM) studies are based in part on transfer functions that incorporated modern species absent from Pliocene assemblages as well as Pliocene species now extinct (Dowsett and Poore, 1990).

The lack of evidence in support of the constancy of environmental tolerance of species remains a stumbling block for paleoenvironmental reconstruction. A second obstacle is the inability to establish high-confidence deep-time chronology and correlation among multiple deep-sea sites where the sediment accumulation rate is relatively low and bioturbation is common. Although a plethora of Piacenzian planktonic foraminiferal census data exist, the temporal density of samples within and between cores is highly variable, thus hindering the accurate correlation and calibration of coeval samples from different localities on the basis of current age models (Dowsett and others, 2019).

In this report, these concerns are addressed by presenting an alternative approach to paleotemperature estimation that uses foraminiferal census data calibrated directly to Piacenzian temperatures derived from alkenone paleothermometry, 
thereby eliminating the need for stationarity in environmental preferences beyond the time interval covered by the study. We averaged both faunal abundance data and alkenone data, within a defined stratigraphic interval (dated at 3.264-3.025 Ma), to accommodate the uneven temporal distribution of samples within and between core sites. This averaging effectively passed the data through a low-pass filter, thereby eliminating the possibility of estimating highfrequency variability. We accepted this limitation in order to establish general warming and cooling trends in Pliocene time series.

\section{Materials and Methods}

\section{Chronology}

In our study, we focused on a period of warm and stable climate (relative to high-amplitude Pleistocene glacialinterglacial cycles) positioned within the Piacenzian Stage known as the PRISM3 interval or mid-Piacenzian Warm Period (mPWP) (fig. 1). It extends from the Marine Isotope Stage (MIS) M2/M1 boundary (3.264 Ma) to the G21/G20 boundary (3.025 Ma) in the middle part of the Gauss normal polarity Chron (Dowsett and others, 2010, 2016). As defined, the interval lasted about 240,000 years ( $240 \mathrm{kyr})$ and ranged from C2An2r (Mammoth reversed polarity) to near the bottom of C2An1 (just above Kaena reversed polarity). This interval correlates in part with planktonic foraminiferal zones PL3 (Sphaeroidinellopsis seminulina Highest Occurrence Zone), PL4 (Dentoglobigerina altispira Highest Occurrence Zone), and PL5 (Globorotalia miocenica Highest Occurrence Zone). Within the bounding positive $\delta^{18} \mathrm{O}$ excursions that mark glacial stages M2 and G20, and excepting glacial stage KM2 at $\sim 3.1 \mathrm{Ma}$, benthic foraminiferal oxygen isotope values in this interval are equal to or isotopically lighter than those measured today.

\section{Faunal Census Data}

Planktonic foraminiferal abundance data were selected from the PRISM3 interval of 31 sites in the North Atlantic Ocean (Dowsett and others, 2015; Robinson and others, 2019); the sites were drilled by the Deep Sea Drilling Project (DSDP), Ocean Drilling Program (ODP), and International Ocean Discovery Program (IODP). The temporal distribution of samples within this interval at each site is highly variable, and establishing synchronous samples from the different localities, based upon existing age models, is unrealistic. Therefore, samples collected from within the stratigraphic interval dated at 3.264-3.025 Ma at each site were averaged to obtain mean abundances. Species with mean abundances $\leq 1$ percent were deleted. The resulting dataset contains percent mean abundance data for 23 counting categories at each of the 31 North Atlantic sites (table 1). Taxonomic concepts are those of Parker (1962, 1967), Blow (1969), and Dowsett and Robinson (2007). A species list is provided in appendix 1.

\section{Sea Surface Temperature Data}

The $U_{37}^{K^{\prime}}$ (unsaturated ketones with 37 carbon atoms) unsaturation index was used to obtain SST estimates from the PRISM3 interval of 17 sites in the North Atlantic (table 1). Temperature estimates using this technique generally have an analytical error of $\pm 0.1^{\circ} \mathrm{C}$ (Herbert and others, 1995; Lawrence and others, 2007). All temperature estimates were calibrated by using the method of Müller and others (1998) and have a calibration uncertainty of $\pm 1.38^{\circ} \mathrm{C}$ (Lawrence and others, 2007). Alkenone data used have been previously published (Robinson and others, 2008; Lawrence and others, 2009; Herbert and others, 2010; Lawrence and others, 2010; Naafs and others, 2010; Khélifi and others, 2012; Badger and others, 2013; Dowsett and others, 2017, 2019). As with the faunal data, a single SST estimate was obtained for the PRISM3 stratigraphic interval, which represents the mean of individual $U_{37}^{K^{\prime}}$ estimates for samples dated between 3.264 and 3.025 Ma at each site (table 1).

\section{Quantitative Analysis}

Q-mode factor analysis (Klovan and Imbrie, 1971) was used to reduce the dimensionality of the Pliocene faunal data. The process is summarized by the following equation:

$$
U_{p}=B_{p} F_{p}+E
$$

where $\boldsymbol{U}_{\boldsymbol{p}}$ represents the normalized Pliocene foraminiferal census; $\boldsymbol{B}_{p}$ represents the varimax factor loadings matrix providing the contribution of each factor to the assemblage; $\boldsymbol{F}_{\boldsymbol{p}}$ represents the factor description (scores) matrix, which describes the composition of the factors; and $\boldsymbol{E}$ represents an error matrix.

Sample communality $\left(h^{2}\right)$ is provided to assess how well the factor model explains the data in each sample. Communality is expressed as the sum of the squares of the factor loadings $(f)$, for factors 1 through $n$ :

$$
h^{2}=\sum_{1}^{n} f_{n}^{2}
$$

A sample communality of 1 indicates a perfect fit of model and data, with $\boldsymbol{E}=0$. 


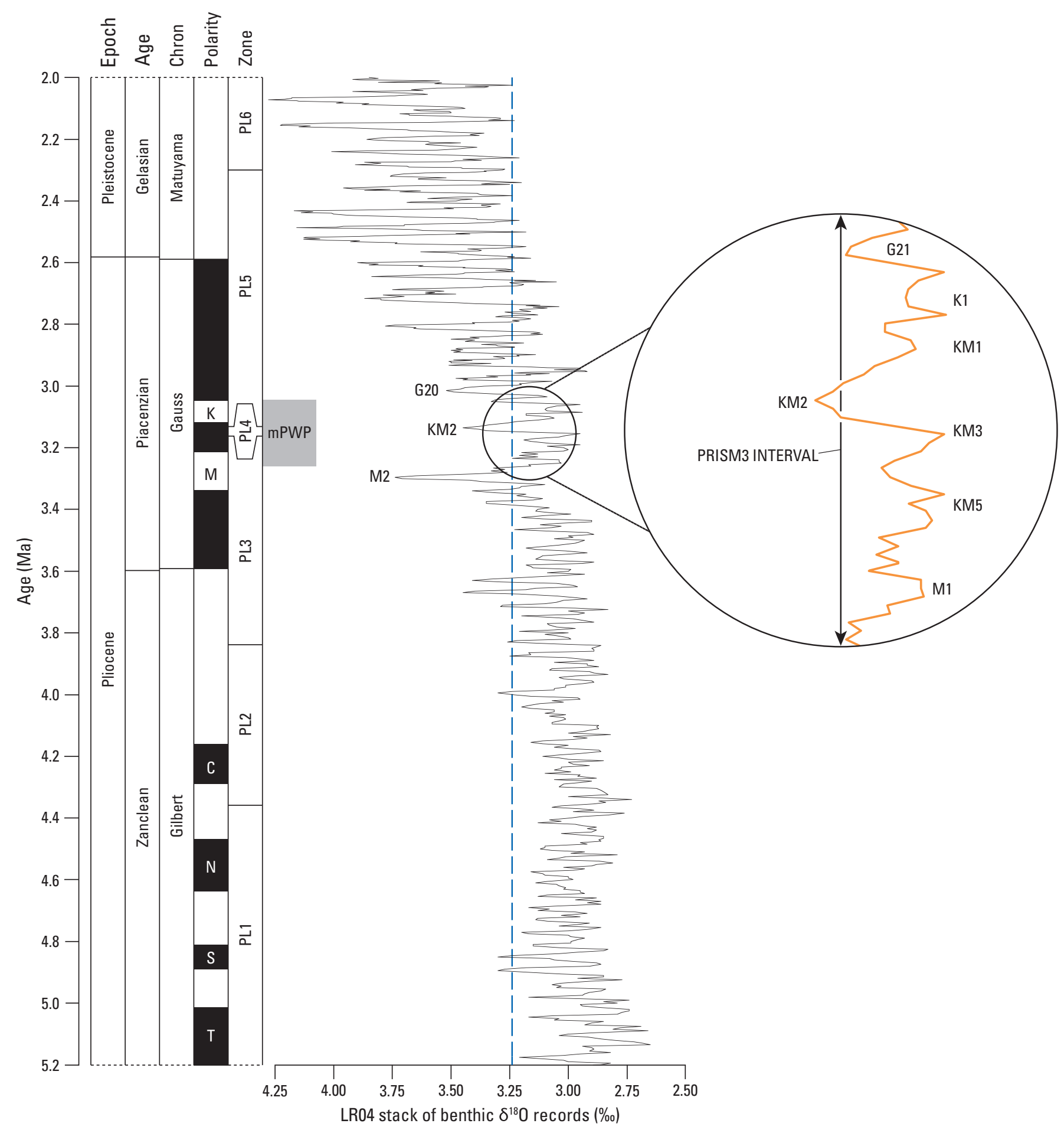

Figure 1. Graph showing the PRISM3 interval (also known as the mid-Piacenzian Warm Period [mPWP]) in relation to paleomagnetic reversal stratigraphy, planktonic foraminiferal zones, and the long-term climate evolution of the Pliocene Epoch. The LRO4 benthic oxygen isotope stack and time scale are from Lisiecki and Raymo (2005); $\delta^{18} 0$ values are in parts per thousand $(\% \circ)$. The vertical dashed line shows the $\delta^{18} 0$ value for the present-day ocean. The PRISM3 stratigraphic interval (dated at 3.264-3.025 million years ago [Ma]) is shown relative to Marine Isotope Stages M2, M1, KM5, KM3, KM2, KM1, K1, G21, and G20 from Lisiecki and Raymo (2005). The subchrons in the polarity column of the paleomagnetic data are from $0 \mathrm{gg}$ and others (2016): T, Thvera; S, Sidufjall; N, Nunivak; C, Cochiti; M, Mammoth; K, Kaena. Black segments indicate normal polarity, and white segments indicate reversed polarity. The planktonic foraminiferal zones PL1 to PL6 for the Pliocene are from Berggren (1973). 
Table 1. Site locations, alkenone-based sea surface temperature estimates, number of samples, and faunal abundance data used in this study.

[Faunal data are from Piacenzian planktonic foraminiferal assemblages from 31 sites in the North Atlantic Ocean. Site prefixes designate three successive drilling programs: DSDP, Deep Sea Drilling Project; ODP, Ocean Drilling Program; IODP, International Ocean Discovery Program. Latitude values are positive for sites north of the Equator and negative for sites south of the Equator. Longitude values are negative for sites west of the Prime Meridian. Numbers for the species are mean abundances in percent, as explained in the text. For $N$. atlantica, we separated dextral (d) and sinistral (s) varieties into distinct counting categories. Other terms: ${ }^{\circ} \mathrm{C}$, degrees Celsius; $\sigma$, standard deviation; SST, sea surface temperature]

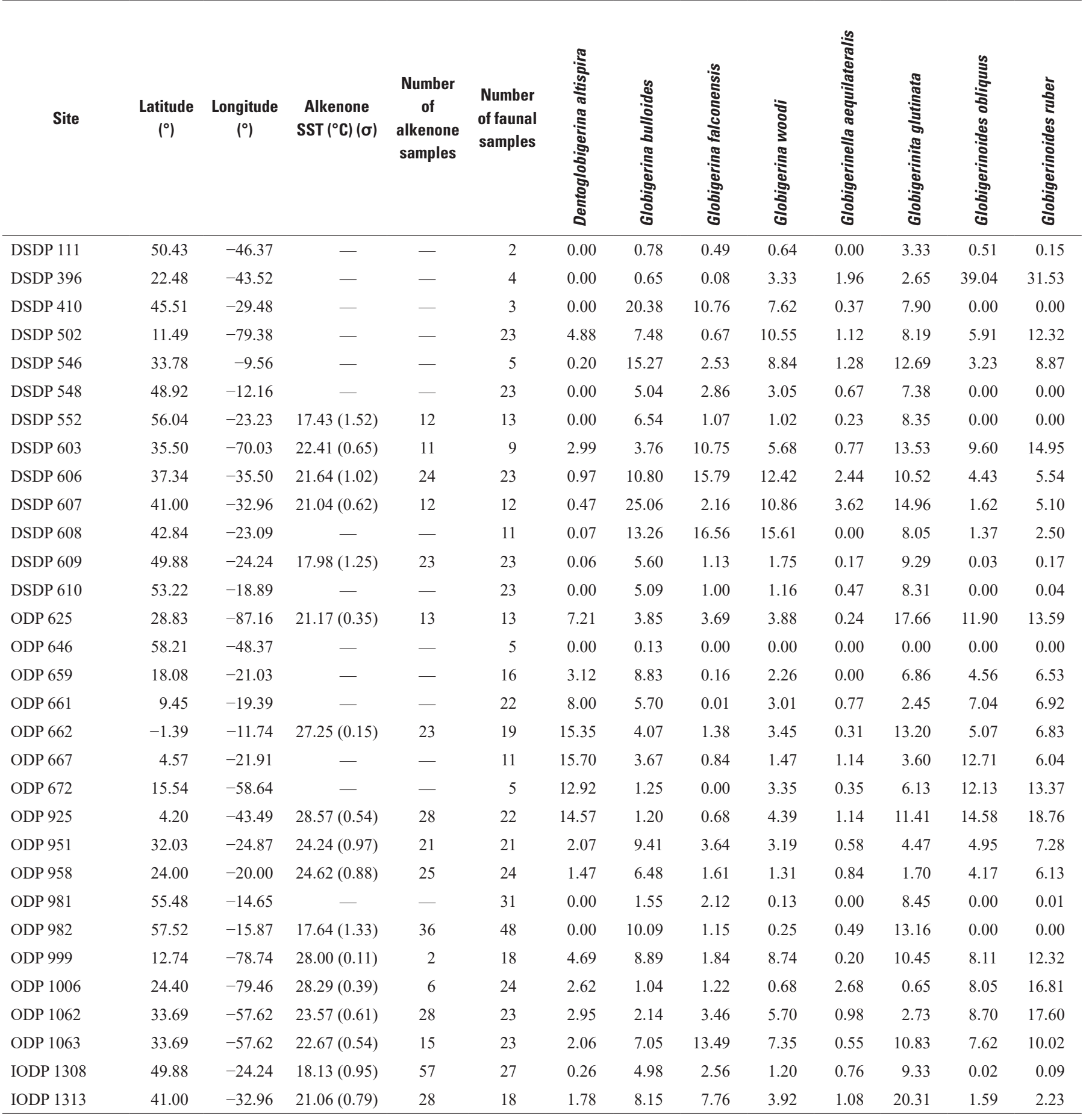


Table 1. Site locations, alkenone-based sea surface temperature estimates, number of samples, and faunal abundance data used in this study.-Continued

[Faunal data are from Piacenzian planktonic foraminiferal assemblages from 31 sites in the North Atlantic Ocean. Site prefixes designate three successive drilling programs: DSDP, Deep Sea Drilling Project; ODP, Ocean Drilling Program; IODP, International Ocean Discovery Program. Latitude values are positive for sites north of the Equator and negative for sites south of the Equator. Longitude values are negative for sites west of the Prime Meridian. Numbers for the species are mean abundances in percent, as explained in the text. For $N$. atlantica, we separated dextral (d) and sinistral (s) varieties into distinct counting categories. Other terms: ${ }^{\circ} \mathrm{C}$, degrees Celsius; $\sigma$, standard deviation; SST, sea surface temperature]

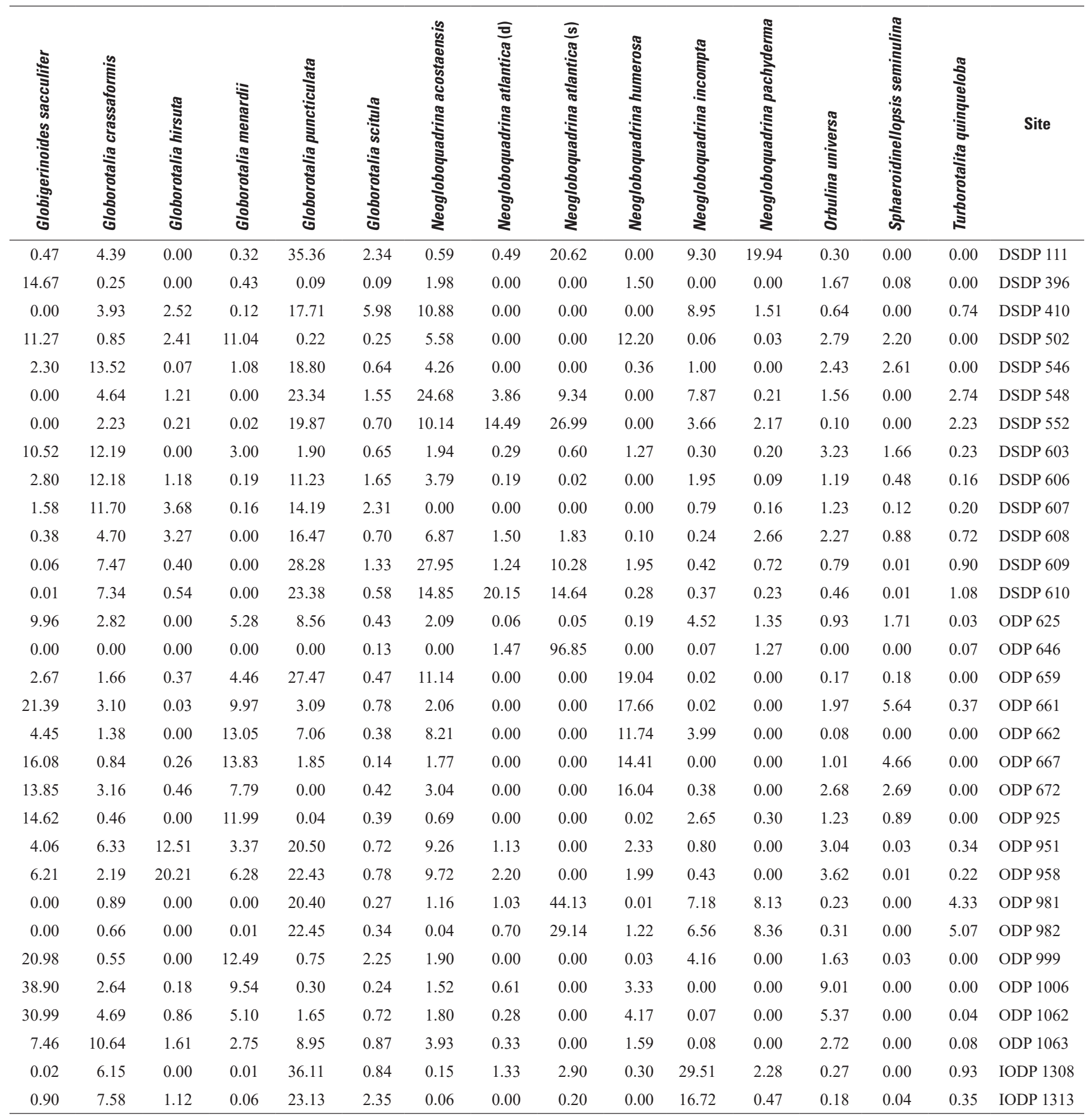


Table 2. Factor loadings explaining the relative contribution of the five factors to the faunal assemblage at each site.

[Sites are identified in table 1. NA, not applicable]

\begin{tabular}{|c|c|c|c|c|c|c|}
\hline Site & Factor 1 & Factor 2 & Factor 3 & Factor 4 & Factor 5 & Communality \\
\hline \multicolumn{7}{|c|}{ Data for individual sites and factors } \\
\hline 111 & 0.2943 & -0.0294 & 0.7074 & 0.3768 & 0.2235 & 0.7798 \\
\hline 410 & 0.7789 & 0.0426 & 0.1590 & 0.4585 & 0.1440 & 0.8647 \\
\hline 502 & 0.2405 & 0.8563 & -0.0335 & 0.2032 & 0.1185 & 0.8476 \\
\hline 548 & 0.4077 & 0.0173 & 0.4353 & 0.7115 & 0.0894 & 0.8702 \\
\hline 552 & 0.2475 & 0.0278 & 0.8359 & 0.4163 & 0.0082 & 0.9340 \\
\hline 603 & 0.6050 & 0.7254 & 0.0679 & -0.0341 & -0.1400 & 0.9176 \\
\hline 606 & 0.8903 & 0.2956 & 0.1002 & 0.1885 & -0.0609 & 0.9293 \\
\hline 607 & 0.8305 & 0.2078 & 0.1117 & 0.2229 & 0.0788 & 0.8013 \\
\hline 625 & 0.5313 & 0.7399 & 0.1621 & 0.0653 & 0.1825 & 0.8936 \\
\hline 646 & -0.1522 & 0.0412 & 0.9146 & -0.0922 & -0.1666 & 0.8975 \\
\hline 659 & 0.3244 & 0.3343 & 0.1666 & 0.7071 & 0.3698 & 0.8814 \\
\hline 661 & -0.0036 & 0.8787 & -0.0152 & 0.2513 & 0.1769 & 0.8668 \\
\hline 662 & 0.2462 & 0.6733 & 0.0837 & 0.2920 & 0.5284 & 0.8854 \\
\hline 667 & -0.0427 & 0.8941 & -0.0149 & 0.1685 & 0.3013 & 0.9207 \\
\hline 672 & 0.0258 & 0.9366 & -0.0202 & 0.1322 & 0.2130 & 0.9410 \\
\hline 925 & 0.1949 & 0.9111 & 0.0388 & -0.0683 & 0.1130 & 0.8871 \\
\hline 1062 & 0.1391 & 0.8964 & 0.0008 & 0.1013 & -0.2476 & 0.8945 \\
\hline 1063 & 0.7533 & 0.5648 & 0.0886 & 0.1930 & -0.0994 & 0.9414 \\
\hline 1308 & 0.5279 & -0.0362 & 0.3667 & 0.3554 & 0.4514 & 0.7446 \\
\hline 1313 & 0.7780 & 0.1178 & 0.2819 & 0.2222 & 0.4032 & 0.9106 \\
\hline \multicolumn{7}{|c|}{ Percent variance explained by Factors 1 through 5} \\
\hline NA & 49.37 & 21.71 & 8.74 & 5.11 & 3.24 & NA \\
\hline \multicolumn{7}{|c|}{ Cumulative percent variance explained by Factors 1 through 5} \\
\hline NA & 49.37 & 71.08 & 79.82 & 84.93 & 88.17 & NA \\
\hline
\end{tabular}


Table 3. Factor scores for the five-factor model indicating influence of taxa from 31 sites on factors.

[Taxa are listed alphabetically by genus and species. (d), dextral; (s), sinistral]

\begin{tabular}{lrrrrr}
\hline \multicolumn{1}{c}{ Taxon } & Factor $\mathbf{1}$ & Factor $\mathbf{2}$ & Factor 3 & Factor $\mathbf{4}$ & Factor $\mathbf{5}$ \\
\hline Dentoglobigerina altispira & -0.404 & 1.292 & -0.036 & -0.146 & 1.955 \\
Globigerina bulloides & 2.002 & 0.152 & -0.162 & 0.430 & -0.001 \\
Globigerina falconensis & 1.916 & 0.058 & -0.123 & -0.471 & -0.895 \\
Globigerina woodi & 1.578 & 0.482 & -0.246 & -0.265 & -0.476 \\
Globigerinella aequilateralis & 0.181 & 0.117 & -0.012 & -0.014 & -0.097 \\
Globigerinita glutinata & 2.076 & 0.802 & 0.672 & -0.906 & 1.414 \\
Globigerinoides obliquus & 0.231 & 1.798 & 0.045 & -0.254 & -0.339 \\
Globigerinoides ruber & 0.646 & 2.162 & -0.035 & -0.248 & -0.945 \\
Globigerinoides sacculifer & -0.499 & 2.873 & 0.047 & 0.357 & -1.210 \\
Globorotalia crassaformis & 1.585 & 0.176 & -0.036 & 0.053 & -0.695 \\
Globorotalia hirsuta & 0.035 & 0.018 & -0.440 & 1.398 & -0.813 \\
Globorotalia menardii & -0.507 & 1.467 & -0.127 & 0.310 & 1.167 \\
Globorotalia puncticulata & 1.553 & -0.455 & 1.296 & 2.940 & 1.176 \\
Globorotalia scitula & 0.287 & 0.006 & 0.000 & 0.048 & 0.042 \\
Neogloboquadrina acostaensis & -0.165 & 0.131 & -0.071 & 2.875 & -0.727 \\
Neogloboquadrina atlantica $(\mathrm{d})$ & -0.218 & -0.037 & 0.536 & 0.788 & -0.661 \\
Neogloboquadrina atlantica $(\mathrm{s})$ & -0.731 & 0.199 & 4.368 & -0.452 & -0.795 \\
Neogloboquadrina humerosa & -1.054 & 1.245 & -0.312 & 1.090 & 1.919 \\
Neogloboquadrina incompta & 0.780 & -0.126 & 0.629 & -0.545 & 1.970 \\
Neogloboquadrina pachyderma & 0.070 & -0.030 & 0.771 & -0.220 & 0.361 \\
Orbulina universa & 0.102 & 0.403 & -0.061 & 0.322 & -0.644 \\
Sphaeroidinellopsis seminulina & -0.056 & 0.282 & -0.030 & 0.009 & 0.278 \\
Turborotalita quinqueloba & 0.009 & -0.011 & 0.287 & 0.033 & 0.001 \\
\hline
\end{tabular}

We developed a simple transfer function by regressing Pliocene environmental data on the factor loadings $\left(\boldsymbol{B}_{p}\right)$ according to the following equation:

$$
S S T_{\text {est }}=\boldsymbol{B}_{p} \boldsymbol{K}+k_{0}
$$

where $S S T_{\text {est }}$ represents the environmental estimate (in this case $S S T), \boldsymbol{K}$ is a vector of regression coefficients, and $k_{0}$ is the intercept of the equation. We used Q-mode cluster analysis and the Unweighted Pair Group Method with Arithmetic Mean (UPGMA) to define groups (based upon loadings in each sample). Euclidean distance between samples was calculated using the following equation:

$$
D_{x, y}=\sqrt{\sum_{1}^{n}\left(x_{n}-y_{n}\right)^{2}}
$$

where the distance $(D)$ between two samples $x$ and $y$ is the square root of the summation, for factors 1 to $n$, of the square of the distance between samples $x$ and $y$.

\section{Results}

\section{Assemblage Analysis}

Factor analysis reduced the 23 counting categories in the Piacenzian time-averaged faunal census to five factors. Tables 2 and 3 summarize this analysis and indicate that while the five factors explain 88 percent of the variance, the first three factors cumulatively account for $\sim 80$ percent of the variance in the original faunal data. Sample communalities indicate that the five-factor model explains between 80 and 99 percent of the faunal assemblage data in a sample.

Samples with high loadings on Factor 1 (fig. 2) are dominated by temperate taxa: Globigerina bulloides, Globigerina falconensis, Globigerina woodi, Globigerinita glutinata, Globorotalia crassaformis, and Globorotalia puncticulata (fig. 3). High loadings on Factor 2 indicate greater abundances of species with warm water affinities: Dentoglobigerina altispira, Globigerinoides obliquus, Globigerinoides ruber, Globigerinoides sacculifer, Globorotalia menardii, and Neogloboquadrina humerosa (figs. 2, 3). Factor 3 has high loadings on samples with greater abundances of 


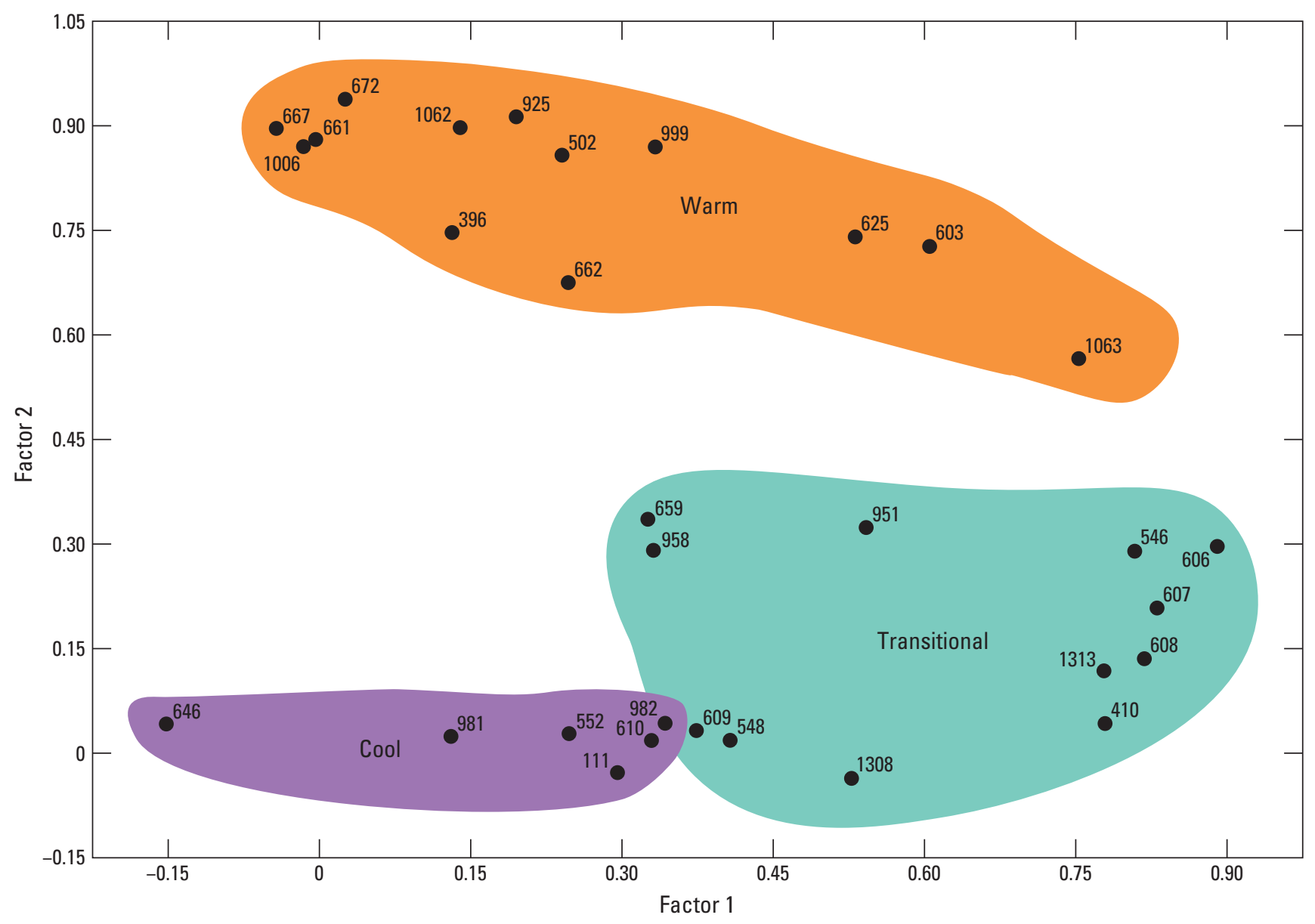

Figure 2. Graph of results of factor analysis of Piacenzian planktonic foraminiferal assemblages showing sample loadings on Factor 1 and Factor 2 (table 2). Numbers by plotted points identify core sites where samples yielding the assemblages were obtained (table 1). Three groups of site numbers that are defined by shading and labeled "Warm," "Transitional," and "Cool" indicate sources of sample assemblages having affinities for warm, transitional, or cool water.

Neogloboquadrina atlantica (s), Neogloboquadrina pachyderma, Neogloboquadrina incompta, Globigerinita glutinata, and Globorotalia puncticulata (fig. 3). These taxa are generally found at higher latitudes and represent cool to cold conditions. The first three factors are therefore interpreted to represent transitional, warm, and cool end-member assemblages, respectively (figs. 2, 3).

Factors 4 and 5 do not have consistent spatial representations and instead may indicate seasonal changes in the water column that influence the production and distribution of Foraminifera. For example, Factor 4 has highest loadings on samples with greater abundances of the thermocline dwellers Globorotalia puncticulata, Neogloboquadrina humerosa, and Neogloboquadrina acostaensis and the subthermocline dwellers Globorotalia crassaformis and Globorotalia hirsuta (fig. 3). Factor 5 has highest loadings on samples containing greater abundances of Neogloboquadrina incompta, Neogloboquadrina humerosa, Globorotalia puncticulata, Globorotalia menardii, Globigerinita glutinata, and
Dentoglobigerina altispira. The difficulty in parsing the meaning of Factors 4 and 5 may also stem from the fact that mean abundances are being used (see "Discussion" section below).

To aid interpretation, factor loadings were clustered by using an unweighted pair group algorithm (UPGMA), and the cluster groups were mapped geographically (fig. 4). Three main groups of samples are defined that are, as expected, similar to Factors 1-3 (fig. 4). Samples in the low latitudes have assemblages coinciding with the warm factor. A subgroup can be distinguished along its southern margin tracing the southern limb of the North Atlantic Gyre and represents the warmest conditions (fig. 4). The other sites within this group are located along the general path of the Gulf Stream or in more subtropical regions of the North Atlantic Gyre.

Sites belonging to the cool group defined by cluster analysis are the same as those showing high loadings on Factor 3 (figs. 3, 4). A third group of sites is defined by the cluster analysis and occupies the eastern and northeastern region of the North Atlantic. This group extends beyond the region 


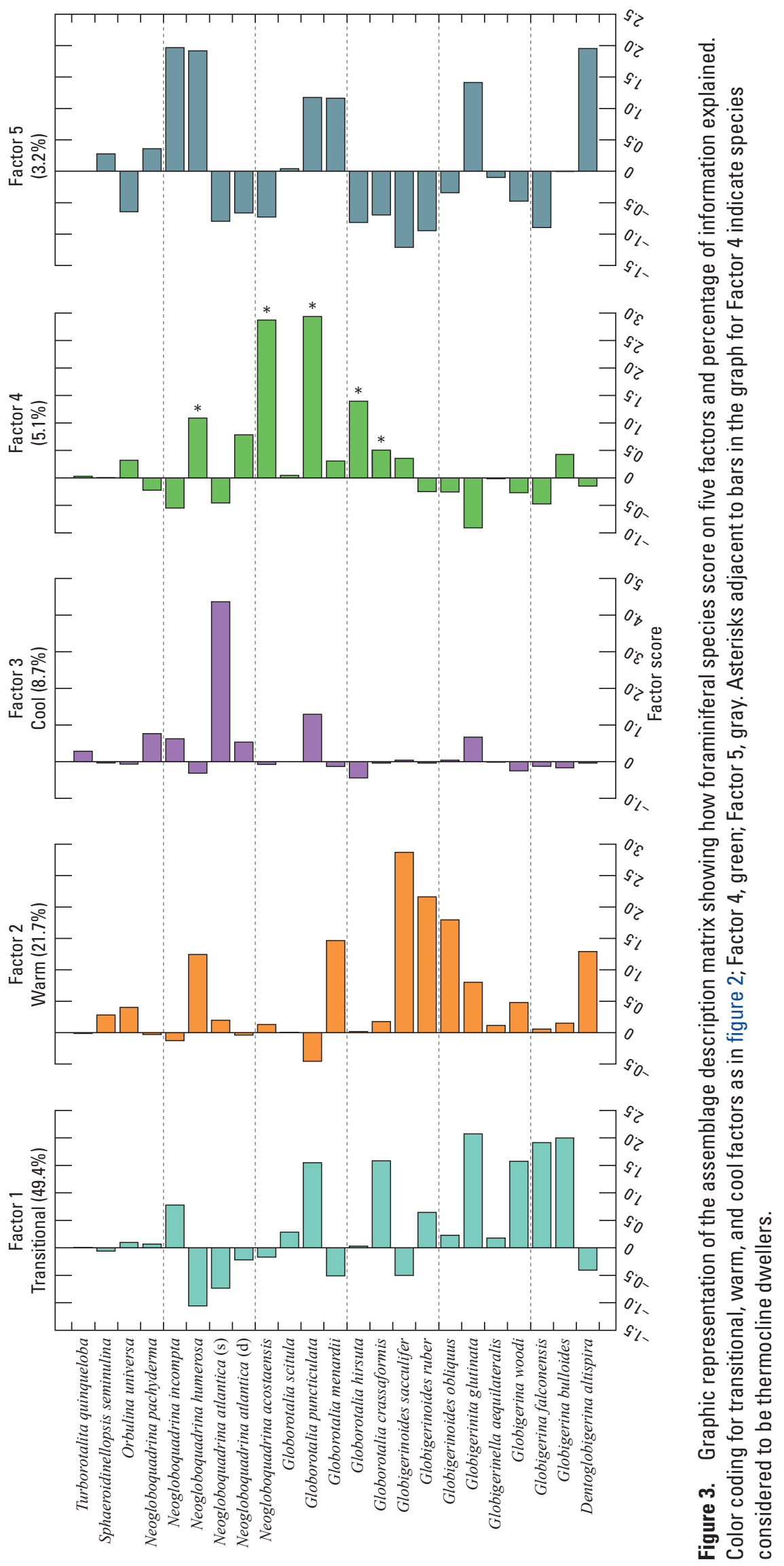



Localities $\boldsymbol{A}$ Transitional Cool Warm
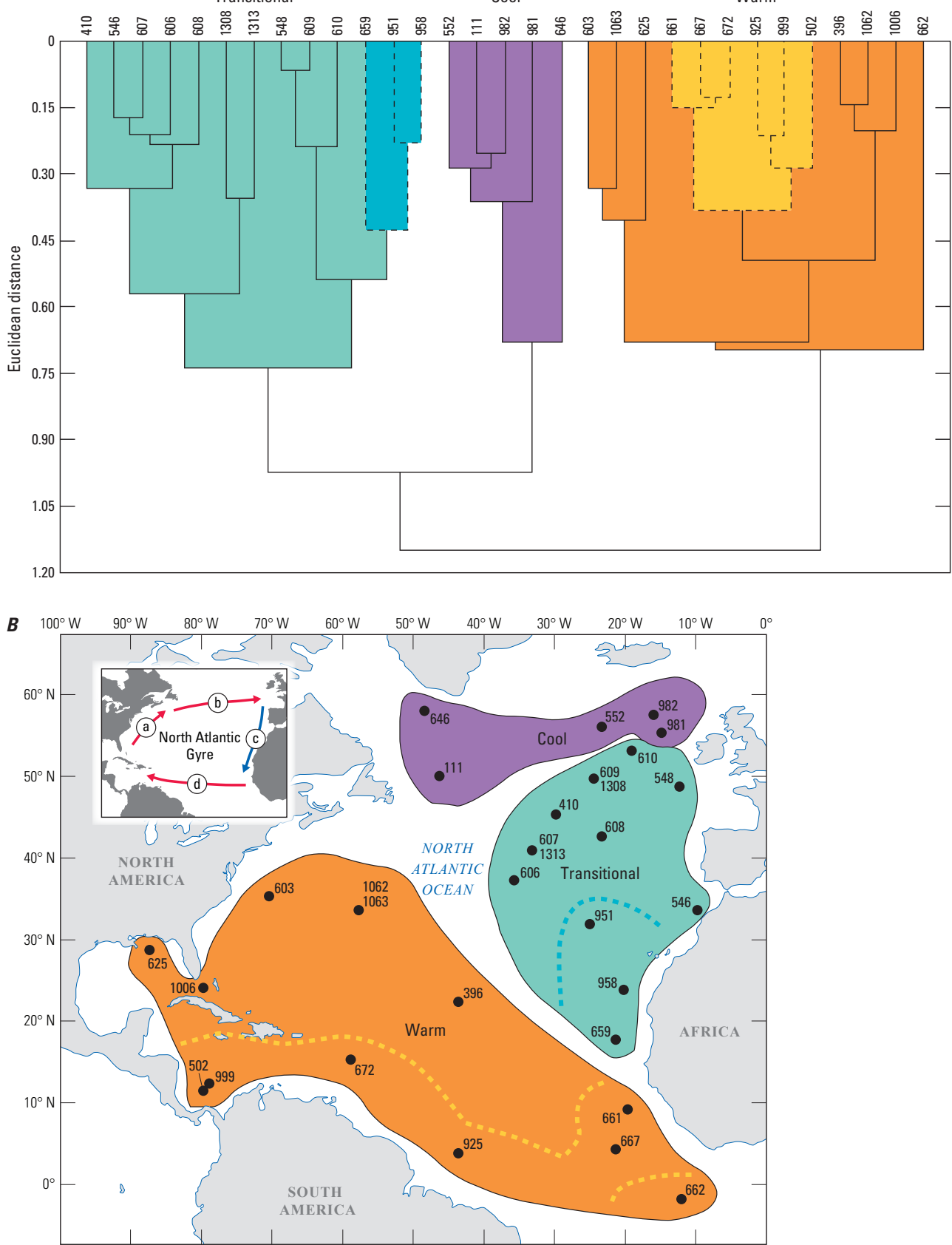

Figure 4. Dendrogram and map showing results of cluster analysis of planktonic foraminiferal assemblages from 31 sites and geographic distribution of cluster groups. $A$, Dendrogram of Q-mode cluster analysis of 31 sites representing the PRISM3 interval of the North Atlantic Ocean, using unweighted pair-group average linking of Euclidean distances calculated on factor loadings; transitional (teal), cool (purple), and warm (orange). The blue subcluster within the transitional cluster has dashed borders and represents a subgroup of sites in the eastern Atlantic influenced by the African margin. The lighter orange group within the warm cluster has dashed lines and represents a subgroup of sites that indicate more tropical conditions and that have distinct assemblage differences from the remainder of the warm cluster. $B$, Cluster groups in map view. Colors are the same as in part $A$. Subgroups are indicated by dashed lines. The inset map shows major currents around the North Atlantic Gyre: (a) Gulf Stream, (b) North Atlantic Drift, (c) Canary Current, and (d) Northern Equatorial Current. Red arrows indicate warm currents, and the blue arrow indicates a cool current. 
where the transitional factor is most expressed and includes sites with a cool influence in the north and a warm influence in the south. Within this group, cluster analysis distinguishes a subgroup of sites heavily influenced by the Canary Current and sedimentation along the African margin (fig. 4).

\section{Paleotemperature Equation}

Multiple regression was used to write an equation relating the five factors $\left(f_{1}-f_{5}\right)$ to mean annual SST derived using the $U_{37}^{K^{\prime}}$ index. The coefficient of determination $\left(\mathrm{R}^{2}\right)$ for the equation is 0.87 , and the root mean square (RMS) error is $\pm 1.38^{\circ} \mathrm{C}$.

$$
\begin{aligned}
S S T= & -0.15\left(f_{1}\right)+11.3\left(f_{2}\right)-2.62\left(f_{3}\right) \\
& +4.04\left(f_{4}\right)+4.74\left(f_{5}\right)+17.24
\end{aligned}
$$

This equation is constrained between $\sim 17$ and $29^{\circ} \mathrm{C}$. Comparison of $U_{37}^{K^{\prime}}$ SST estimates and faunal SST estimates derived using the equation above, for 17 localities where we have both, show residuals less than $2{ }^{\circ} \mathrm{C}$ and do not exhibit any obvious latitudinal trends. Eleven of the 17 sites show alkenone estimates higher than faunal estimates.

This equation was applied to factor loadings from the 14 sites without alkenone records to estimate SST for those samples (table 1). Figure 5 shows the spatial distribution of SST estimates based upon alkenones and the transformed faunal data.

\section{Discussion}

\section{Use of New Transfer Function}

The assumption of stationarity, that Piacenzian and modern individuals of the same species have similar environmental preferences, has plagued pre-Quaternary paleotemperature reconstructions based on fossil assemblage data calibrated to modern coretop assemblage data. Kucera and Schönfeld (2007) cautioned that the nature of the modern foraminiferal fauna is a product of the most recent extinctions and diversification. Therefore, environmental proxies based on assemblages should not be interpreted quantitatively in sediments older than the late Pliocene. One solution to this problem is to disregard the modern faunal preferences and directly calibrate Piacenzian taxa to
Piacenzian temperatures. The extensive Piacenzian faunal census datasets and paired Piacenzian $U_{37}^{K^{\prime}}$ SST values allow for the development of a factor analytic transfer function ideally suited to provide SST estimates at sites lacking alkenone analyses. The combination of SST estimates derived from alkenone analyses and the new transfer function provides a reconstruction of mean PRISM3 interval (3.264-3.025 Ma) SST in the North Atlantic with improved spatial resolution (fig. 5).

\section{North Atlantic Sea Surface Temperature}

Dowsett and others (2019) showed the North Atlantic latitudinal surface temperature gradient, calculated using $U_{37}^{K^{\prime}}$ SST estimates confined to MIS KM5c, to be essentially the same as that originally reconstructed using multiple temperature proxies and a temporally more broad, less constrained time slab (Dowsett and others, 1992). The spatial pattern of alkenone SST estimates and those from the new transfer function also show good agreement (fig. 5). These estimates, based upon an independent calibration, confirm the pattern of spatial SST variability documented in previous Pliocene reconstructions of the North Atlantic (Dowsett, 2007; Dowsett and others, 1992, 2010, 2012). This expanded set of comparison data will be useful for future data-model comparison.

The SST estimates from ODP Sites 981 and 982 , located close to each other (fig. 5), differ by $\sim 2{ }^{\circ} \mathrm{C}\left(15.7^{\circ} \mathrm{C}\right.$ and $17.6{ }^{\circ} \mathrm{C}$, respectively). The Site 982 record is based on alkenones (Lawrence and others, 2009; Dowsett and others, 2017), whereas the estimates from Site 981 are derived from faunal assemblages and the transfer function presented here. To better understand why these estimates are different, we first applied the transfer function to the Site 982 faunal assemblage. That analysis provides an SST estimate only $0.5^{\circ} \mathrm{C}$ cooler than the alkenone estimate. This estimate and the high communalities for both Sites 981 and 982 (table 1) suggest that transfer function performance is robust. The Site 982 samples were collected from the entire PRISM3 stratigraphic interval, whereas the Site 981 data are restricted to an interval of cooling correlated to the $\delta^{18} \mathrm{O}$ enrichment associated with the MIS M1-MIS KM6 transition. The primary difference between the mean assemblages at the two sites is a higher abundance of $N$. atlantica (s) at Site 981. This increases the strength of the cool assemblage, and, in turn, results in a colder transfer function estimate (table 1). For comparison, applying the transfer function to the same cool interval at Site 982 results in an estimated SST of $16.0^{\circ} \mathrm{C}$, only $0.3{ }^{\circ} \mathrm{C}$ warmer than the estimate at Site 981. 


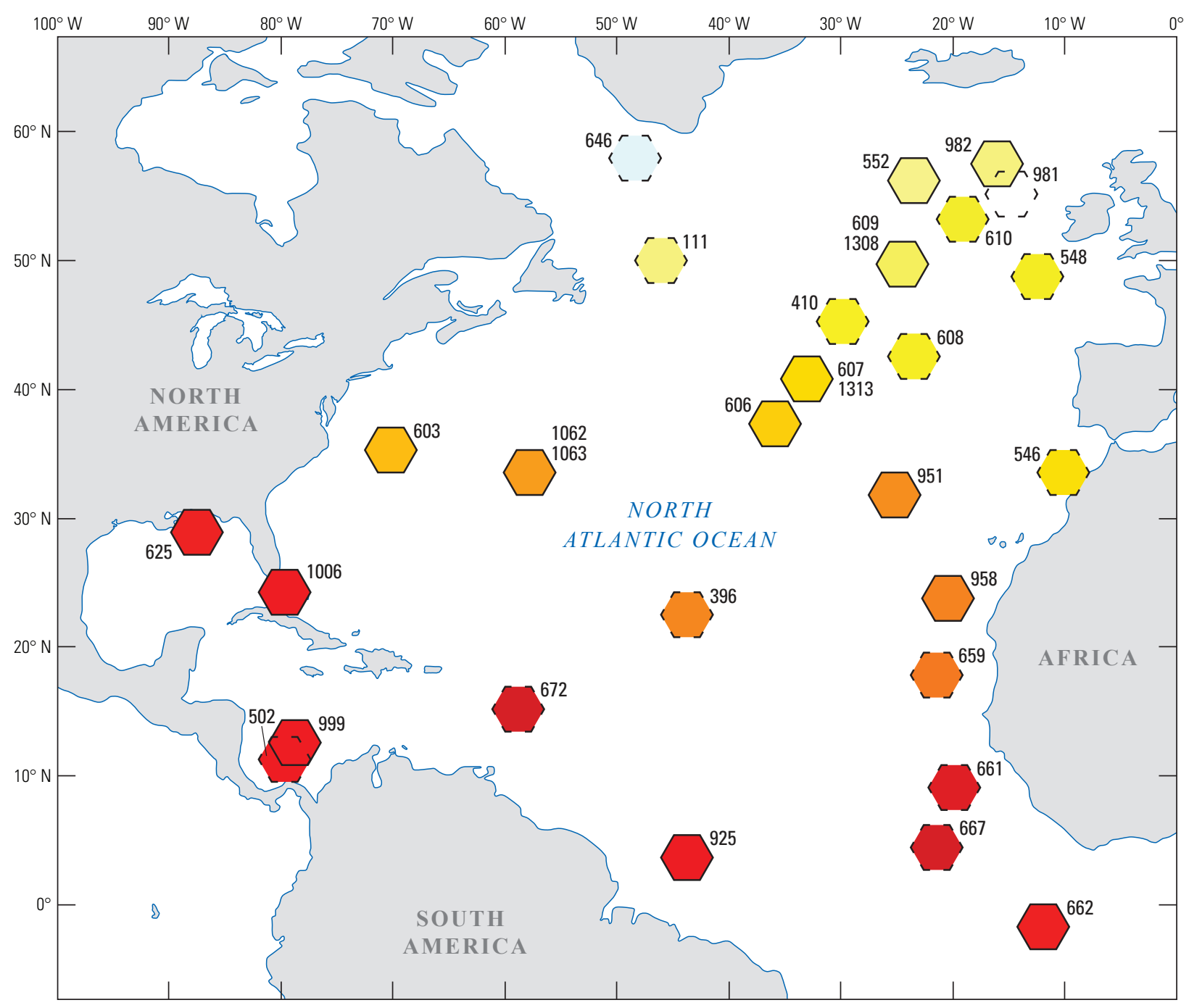

EXPLANATION

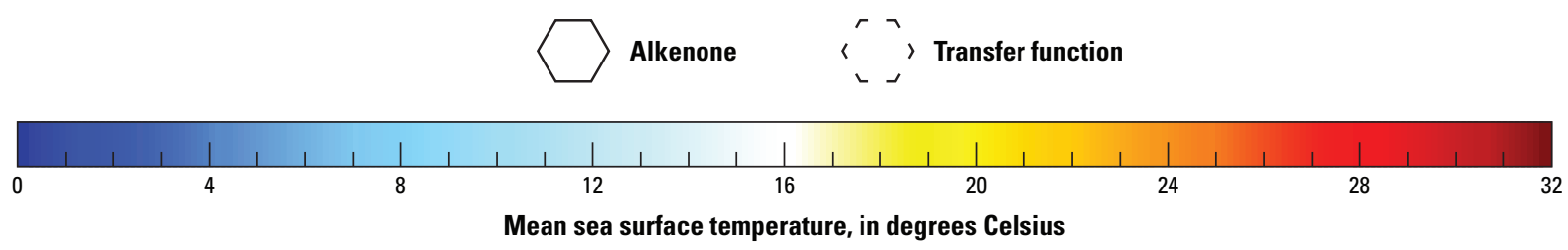

Figure 5. Map showing PRISM3 mean sea surface temperatures (SST) for 31 sites in the North Atlantic 0cean. Symbols with solid borders are $U_{37}^{K}$ (alkenone) SST estimates. Symbols with dashed borders are estimates derived by using a new transfer function. 


\section{Summary and Conclusions}

Previous faunal transfer functions relied upon calibration of modern taxa to temperature or to another oceanographic variable. For Pliocene applications, fossil faunas were, out of necessity, assessed in terms of the modern model to estimate paleoenvironmental conditions. Thus, to use faunal techniques to estimate Pliocene temperature, stationarity was consequently assumed over the last 3 million years. If we instead assume stationarity of environmental tolerances only over a narrow interval of time, and calibrate directly to that same interval, our assumptions become more likely, and precise chronology within the interval becomes less important.

We explore another way to estimate Pliocene paleoenvironments without assuming environmental stationarity. We use independent alkenone-based mean paleotemperature estimates to directly calibrate mean abundance data of Pliocene Foraminifera from within the PRISM3 time slab (3.264 Ma-3.025 Ma). Initial results are encouraging in that Pliocene faunal census data, converted to mean annual SST estimates, fit well with alkenone-based estimates. This methodology allows utilization of the large amount of PRISM faunal census data in order to expand spatial SST reconstructions.

The availability of $U_{37}^{K^{\prime}}$ SST estimates on an increasing number of Pliocene sequences, combined with the availability of taxonomically consistent global Pliocene planktonic foraminiferal census data, provides a unique opportunity to assess the assumption of stationarity, to help evaluate preferences assumed for now extinct taxa, and to estimate paleotemperatures.

It is important to remember that attempts at reconstructing a single environmental variable, like mean annual SST, are oversimplifications of complex and variable interactions between individuals and the $n$-dimensional hypervolume or niche (Hutchinson, 1957) within which a species of planktonic foraminifer can survive. While temperature is a first-order control on foraminifer abundance and distribution, many other factors (such as productivity, salinity, and nutrients) also play a role.

Advances in chronology allow for more precise correlations between sedimentary archives, but the fundamental faunal assemblage-based signals preserved in sedimentary records are still limited by the degree of time averaging inherent in the signal and added to the signal by postdepositional processes (such as sediment mixing due to bioturbation). During life, Foraminifera respond to a range of sub-annual processes that result in the discontinuous and seasonal rain of material to the sea floor. Depositional and postdepositional processes serve as a low-pass filter on the already time-averaged environmental signal embedded in foraminiferal assemblages. Our decision to degrade the temporal signal further, by averaging samples within the $\sim 240$ kyr PRISM3 interval, filters out potentially important responses to high-frequency ecological and environmental changes and places constraints on the resolution of paleoenvironmental reconstruction. Nevertheless, comparisons of these SST values with previous data show similar patterns of warmth for the Piacenzian.

\section{References Cited}

Badger, M.P.S., Schmidt, D.N., Mackensen, A., and Pancost, R.D., 2013, High-resolution alkenone palaeobarometry indicates relatively stable $p \mathrm{CO}_{2}$ during the Pliocene (3.3-2.8 Ma): Philosophical Transactions of the Royal Society, A, v. 371, no. 2001, article 20130094, 16 p., accessed March 15, 2014, at https://doi.org/10.1098/ rsta.2013.0094.

Berggren, W.A., 1973, The Pliocene time scale-Calibration of planktonic foraminiferal and calcareous nannoplankton zones: Nature, v. 243, no. 5407, p. 391-397.

Blow, W.H., 1969, Late middle Eocene to Recent planktonic foraminiferal biostratigraphy, in Brönnimann, P., and Renz, H.H., eds., Proceedings of the First International Conference on Planktonic Microfossils, Geneva, 1967: Leiden, E.J. Brill, v. 1, p. 199-422.

CLIMAP Project Members, 1984, The last interglacial ocean: Quaternary Research, v. 21, no. 2, p. 123-224.

Cline, R.M., and Hays, J.D., eds., 1976, Investigation of late Quaternary paleoceanography and paleoclimatology: Geological Society of America Memoir 145, 464 p.

Dowsett, H.J., 2007, The PRISM palaeoclimate reconstruction and Pliocene sea-surface temperature, in Williams, M., Haywood, A.M., Gregory, F.J., and Schmidt, D.N., eds., Deep-time perspectives on climate changeMarrying the signal from computer models and biological proxies: London, Geological Society of London; Micropalaeontological Society Special Publication, [no. 2], p. 459-480.

Dowsett, H.J., Cronin, T.M., Poore, R.Z., Thompson, R.S., Whatley, R.C., and Wood, A.M., 1992, Micropaleontological evidence for increased meridional heat transport in the North Atlantic Ocean during the Pliocene: Science, v. 258, no. 5085, p. 1133-1135.

Dowsett, H.[J.], Dolan, A., Rowley, D., Moucha, R., Forte, A.M., Mitrovica, J.X., Pound, M., Salzmann, U., Robinson, M., Chandler, M., Foley, K., and Haywood, A., 2016, The PRISM4 (mid-Piacenzian) paleoenvironmental reconstruction: Climate of the Past, v. 12, no. 7, p. 1519-1538, accessed June 7, 2019, at https://doi.org/10.5194/cp-121519-2016. 
Dowsett, H.J., Foley, K.M., Robinson, M.M., and Herbert, T.D., 2017, PRISM late Pliocene (Piacenzian) alkenonederived SST data: U.S. Geological Survey data release, accessed June 7, 2019, at https://doi.org/10.5066/ F7959G1S.

Dowsett, H.J., and Poore, R.Z., 1990, A new planktic foraminifer transfer function for estimating Pliocene-Holocene paleoceanographic conditions in the North Atlantic: Marine Micropaleontology, v. 16, nos. 1-2, p. 1-23, accessed August 11, 1993, at https://doi.org/10.1016/03778398(90)90026-I.

Dowsett, H.J., and Robinson, M.M., 2006, Stratigraphic framework for Pliocene paleoclimate reconstruction-The correlation conundrum: Stratigraphy, v. 3, no. 1, p. 53-64.

Dowsett, H.J., and Robinson, M.M., 2007, Mid-Pliocene planktic foraminifer assemblage of the North Atlantic Ocean: Micropaleontology, v. 53, nos. 1-2, p. 105-126.

Dowsett, H.[J.], Robinson, M., and Foley, K., 2015, A global planktic foraminifer census data set for the Pliocene ocean: Scientific Data, v. 2, article 150076, 6 p., accessed December 9, 2018, at https://doi.org/10.1038/sdata.2015.76.

Dowsett, H.J., Robinson, M.M., Foley, K.M., Herbert, T.D., Otto-Bliesner, B.L., and Spivey, W., 2019, The midPiacenzian of the North Atlantic Ocean: Stratigraphy, v. 16, no. 3, p. 119-144, accessed January 28, 2020, at https://doi.org/10.29041/strat.16.3.119-144.

Dowsett, H.J., Robinson, M.M., Haywood, A.M., Hill, D.J., Dolan, A.M., Stoll, D.K., Chan, W.-L., Abe-Ouchi, A., Chandler, M.A., Rosenbloom, N.A., Otto-Bliesner, B.L., Bragg, F.J., Lunt, D.J., Foley, K.M., and Riesselman, C.R., 2012, Assessing confidence in Pliocene sea surface temperatures to evaluate predictive models: Nature Climate Change, v. 2 , no. 5 , p. $365-371$.

Dowsett, H.[J.], Robinson, M., Haywood, A.M., Salzmann, U., Hill, D., Sohl, L.E., Chandler, M., Williams, M., Foley, K., and Stoll, D.K., 2010, The PRISM3D paleoenvironmental reconstruction: Stratigraphy, v. 7, nos. 2-3, p. 123-139.

Herbert, T.D., Peterson, L.C., Lawrence, K.T., and Liu, Z., 2010, Tropical ocean temperatures over the past 3.5 million years: Science, v. 328, no. 5985, p. 1530-1534, accessed March 15, 2019, at https://doi.org/10.1126/science.1185435.

Herbert, T.D., Yasuda, M., and Burnett, C., 1995, Glacialinterglacial sea-surface temperature record inferred from alkenone unsaturation indices, site 893, Santa Barbara Basin: Proceedings of the Ocean Drilling Program, Scientific Results, v. 146 (pt. 2), p. 257-264.
Hutchinson, G.E., 1957, Concluding remarks: Cold Spring Harbor Symposia on Quantitative Biology, v. 22, p. 415-427, accessed March 18, 2019, at https://doi.org/ 10.1101/SQB.1957.022.01.039.

Hutson, W.H., 1980, The Agulhas Current during the late Pleistocene-Analysis of modern faunal analogs: Science, v. 207, no. 4426, p. 64-66, accessed March 18, 2019, at https://doi.org/10.1126/science.207.4426.64.

Imbrie, J., and Kipp, N.G., 1971, A new micropaleontological method for quantitative paleoclimatology-Application to a late Pleistocene Caribbean core, in Turekian, K.K., ed., The late Cenozoic glacial ages: New Haven, Conn., Yale University Press, p. 71-181.

Keigwin, L.D., 1976, Late Cenozoic planktonic foraminiferal biostratigraphy and paleoceanography of the Panama Basin: Micropaleontology, v. 22, no. 4, p. 419-442.

Khélifi, N., Sarnthein, M., and Naafs, B.D.A., 2012, Technical note-Late Pliocene age control and composite depths at ODP site 982, revisited: Climate of the Past, v. 8, no. 1, p. 79-87.

Klovan, J.E., and Imbrie, J., 1971, An algorithm and FORTRAN-IV program for large-scale Q-mode factor analysis and calculation of factor scores: Mathematical Geology, v. 3, no. 1, p. 61-77. [Also available at https://doi.org/ 10.1007/BF02047433.]

Kucera, M., and Schönfeld, J., 2007, The origin of modern oceanic foraminiferal faunas and Neogene climate change, in Williams, M., Haywood, A.M., Gregory, F.J., and Schmidt, D.N., eds., Deep-time perspectives on climate change-Marrying the signal from computer models and biological proxies: London, Geological Society of London; Micropalaeontological Society Special Publication, [no. 2], p. $409-425$.

Lawrence, K.T., Herbert, T.D., Brown, C.M., Raymo, M.E., and Haywood, A.M., 2009, High-amplitude variations in North Atlantic sea surface temperature during the early Pliocene warm period: Paleoceanography, v. 24, no. 2, article PA2218, 15 p., accessed March 15, 2018, at https://doi.org/10.1029/2008pa001669.

Lawrence, K.T., Herbert, T.D., Dekens, P.S., and Ravelo, A.C., 2007, The application of the alkenone organic proxy to the study of Plio-Pleistocene climate, in Williams, M., Haywood, A.M., Gregory, F.J., and Schmidt, D.N., eds., Deep-time perspectives on climate changeMarrying the signal from computer models and biological proxies: London, Geological Society of London; Micropalaeontological Society Special Publication, [no. 2], p. 539-562. 
Lawrence, K.T., Sosdian, S., White, H.E., and Rosenthal, Y., 2010, North Atlantic climate evolution through the PlioPleistocene climate transitions: Earth and Planetary Science Letters, v. 300, nos. 3-4, p. 329-342, accessed March 15, 2019, at https://doi.org/doi:10.1016/j.epsl.2010.10.013.

Lisiecki, L.E., and Raymo, M.E., 2005, A Pliocene-Pleistocene stack of 57 globally distributed benthic $\delta^{18} \mathrm{O}$ records: Paleoceanography, v. 20, no. 1, article PA1003, 17 p., accessed October 14, 2015, at https://doi.org/10.1029/ 2004 PA001071.

Malmgren, B.A., Kucera, M., Nyberg, J., and Waelbroeck, C., 2001, Comparison of statistical and artificial neural network techniques for estimating past sea surface temperatures from planktonic foraminifer census data: Paleoceanography, v. 16, no. 5, p. 520-530. [Also available at https://doi.org/ 10.1029/2000PA000562.]

Malmgren, B.A., and Nordlund, U., 1997, Application of artificial neural networks to paleoceanographic data: Palaeogeography, Palaeoclimatology, Palaeoecology, v. 136, nos. 1-4, p. 359-373.

Müller, P.J., Kirst, G., Ruhland, G., von Storch, I., and RosellMelé, A., 1998, Calibration of the alkenone paleotemperature index $U_{37}{ }^{\prime \prime}$ based on core-tops from the eastern South Atlantic and the global ocean $\left(60^{\circ} \mathrm{N}-60^{\circ} \mathrm{S}\right)$ : Geochimica et Cosmochimica Acta, v. 62, no. 10, p. 1757-1772.

Naafs, B.D.A., Stein, R., Hefter, J., Khélifi, N., De Schepper, S., and Haug, G.H., 2010, Late Pliocene changes in the North Atlantic Current: Earth and Planetary Science Letters, v. 298, nos. 3-4, p. 434-442.
Ogg, J.G., Ogg, G.M., and Gradstein, F.M., 2016, A concise geologic time scale-2016: Amsterdam, Elsevier, 240 p.

Parker, F.L., 1962, Planktonic foraminiferal species in Pacific sediments: Micropaleontology, v. 8, no. 2, p. 219-254.

Parker, F.L., 1967, Late Tertiary biostratigraphy (planktonic Foraminifera) of tropical Indo-Pacific deep-sea cores: Bulletins of American Paleontology, v. 52, no. 235, p. 115-208.

Robinson, M.M., Dowsett, H.J., Dwyer, G.S., and Lawrence, K.T., 2008, Reevaluation of mid-Pliocene North Atlantic sea surface temperatures: Paleoceanography, v. 23, no. 3, article PA3213, 9 p., accessed October 7, 2012, at https://doi.org/ 10.1029/2008PA001608.

Robinson, M.M., Foley, K., Dowsett, H.J., and Spivey, W., 2019, A global planktic foraminifer census data set for the Pliocene ocean, addendum: National Oceanic and Atmospheric Administration, National Centers for Environmental Information [formerly National Climatic Data Center] website, accessed January 4, 2020, at https: //www.ncdc.noaa.gov/paleo/study/27310.

Sabaa, A.T., Sikes, E.L., Hayward, B.W., and Howard, W.R., 2004, Pliocene sea surface temperature changes in ODP site 1125, Chatham Rise, east of New Zealand: Marine Geology, v. 205 , nos. $1-4$, p. 113-125.

Thunell, R.C., 1979, Pliocene-Pleistocene paleotemperature and paleosalinity history of the Mediterranean Sea-Results from DSDP sites 125 and 132: Marine Micropaleontology, v. 4, p. 173-187. 


\section{Appendix 1. Species List}

The following list has names of planktonic foraminiferal species for which abundance data were used in this study (table 1). Samples containing the species were obtained from 31 sites in the North Atlantic Ocean.

Dentoglobigerina altispira (Cushman \& Jarvis, 1936)

Globigerina bulloides d'Orbigny, 1826

Globigerina falconensis Blow, 1959

Globigerina woodi Jenkins, 1960

Globigerinella aequilateralis (Brady, 1879)

Globigerinita glutinata (Egger, 1893)

Globigerinoides obliquus Bolli, 1957

Globigerinoides ruber (d'Orbigny, 1839a)

Globigerinoides sacculifer (Brady, 1877)

Globorotalia crassaformis (Galloway \& Wissler, 1927)

Globorotalia hirsuta (d'Orbigny, 1839b)

Globorotalia menardii (d'Orbigny in Parker, Jones \& Brady, 1865)

Globorotalia puncticulata (Deshayes, 1832)

Globorotalia scitula (Brady, 1882)

Neogloboquadrina acostaensis (Blow, 1959)

Neogloboquadrina atlantica (Berggren, 1972)1

Neogloboquadrina humerosa (Takayanagi \& Saito, 1962)

Neogloboquadrina incompta (Cifelli, 1961)

Neogloboquadrina pachyderma (Ehrenberg, 1862)

Orbulina universa d'Orbigny, 1839a

Sphaeroidinellopsis seminulina (Schwager, 1866)

Turborotalita quinqueloba (Natland, 1938)

\footnotetext{
${ }^{1}$ For $N$. atlantica, we separated dextral (d) and sinistral (s) varieties into distinct counting categories as shown in table 1 .
}

\section{References Cited}

Berggren, W.A., 1972, Cenozoic biostratigraphy and paleobiogeography of the North Atlantic: Initial Reports of the Deep Sea Drilling Project, v. 12, p. 965-1001, 13 pls.

Blow, W.H., 1959, Age, correlation and biostratigraphy of the upper Tocuyo (San Lorenzo) and Pozón Formations, eastern Falcón, Venezuela: Bulletins of American Paleontology, v. 39 , no. 178 , p. 67-252, 19 pls.

Bolli, H.M., 1957, Planktonic Foraminifera from the Oligocene-Miocene Cipero and Lengua Formations of Trinidad, B.W.I.: U.S. National Museum Bulletin 215, p. $97-123$.

Brady, H.B., 1877, II.-Supplementary note on the Foraminifera of the Chalk (?) of the New Britain Group: Geological Magazine (London), new ser., decade 2, v. 4, no. 12 , p. 534-536.

Brady, H.B., 1879, Notes on some of the reticularian Rhizopoda of the "Challenger" Expedition - [part] I.- On new or little known arenaceous types: Quarterly Journal of Microscopical Science, v. 19, new series, no. 73, p. 20-63, 3 pls.

Brady, H.B., 1882, Report on the Foraminifera, in Tizard, [T.H.], and Murray, [J.], Exploration of the Faroe Channel during the summer of 1880, in H.M.'s [Her Majesty's] hired ship "Knight Errant": Proceedings of the Royal Society of Edinburgh, v. 11, no. 11, p. 708-717.

Cifelli, R., 1961, Globigerina incompta, a new species of pelagic Foraminifera from the North Atlantic: Contributions from the Cushman Foundation for Foraminiferal Research, v. 12 , p. $83-86$.

Cushman, J.A., and Jarvis, P.W., 1936, Three new Foraminifera from the Miocene Bowden Marl of Jamaica: Contributions from the Cushman Laboratory for Foraminiferal Research, v. 12, p. 3-5. 
Deshayes, G.P., 1832, Encyclopédie méthodique-Histoire naturelle des vers: Paris, v. 2, 594 p.

d'Orbigny, A.D., 1826, Tableau méthodique de la classe des Céphalopodes: Annales des Sciences Naturelles, v. 7, p. 245-314.

d'Orbigny, A.D., 1839a, Foraminifères, v. 8 of Sagra, R. de la, ed., Histoire physique, politique et naturelle de l'ile de Cuba: Paris, A. Bertrand, 224 p.

d'Orbigny, A.D., 1839b, Foraminifères des Îles Canaries: Histoire naturelle des Iles Canaries, v. 2, no. 2 , p. 120-146. [Also available at https://archive.org/stream/ HistoirenaturelIIWebb\#page/n375/.]

Egger, J.G., 1893, Foraminiferen aus Meeresgrundproben, gelothet von 1874 bis 1876 von S. M. Sch. Gazelle: Abhandlungen der Mathematisch-Physikalischen Classe der Königlich Bayerischen Akademie der Wissenschaften, v. 18, section 2, p. 193-457.

Ehrenberg, C.G., 1862, Über die Tiefgrund-Verhältnissse des Ozeans am Eingange der Davisstrasse und bei Island: Monatsberichte der Königlichen Preussische Akademie der Wissenschaften zu Berlin, p. 275-315.

Galloway, J.J., and Wissler, S.G., 1927, Pleistocene Foraminifera from the Lomita Quarry, Palos Verdes Hills, California: Journal of Paleontology, v. 1, no. 1, p. 35-87.
Jenkins, D.G., 1960, Planktonic Foraminifera from the Lakes Entrance oil shaft, Victoria, Australia: Micropaleontology, v. 6 , no. 4 , p. 345-371.

Natland, M.L., 1938, New species of Foraminifera from off the west coast of North America and from the later Tertiary of the Los Angeles Basin: Bulletin of the Scripps Institution of Oceanography, Technical Series, v. 4, no. 5, p. 137-163.

Parker, W.K., Jones, T.R., and Brady, H.B., 1865, IV.-On the nomenclature of the Foraminifera; Part X. (continued).The species, enumerated by d'Orbigny in the "Annales des Sciences Naturelles," vol. vii, 1826; III. The species illustrated by models: Annals and Magazine of Natural History, ser. 3, v. 16, no. 91, p. 15-41.

Schwager, C., 1866, Fossile Foraminiferen von Kar NikobarReise der Oesterreichischen Fregatte Novara um die Erde in den Jahren 1857, 1858, 1859 unter den Befehlen des Commodore B. von Wüllerstorf-Urbair, Geologischer Theil, Geologische Beobachtung no. 2: Palaeontologische Mittheilung 2, p. 187-268.

Takayanagi, Y., and Saito, T., 1962, Planktonic Foraminifera from the Nobori Formation, Shikoku, Japan: Science Reports of the Tohoku University Second Series (Geology), v. 5, p. 67-105. 


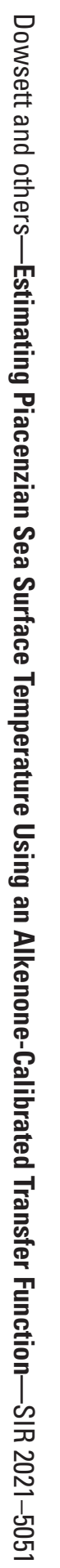

